\title{
BACTERIOLOGICAL QUALITY OF FROZEN AND UNFROZEN PABDA (OMPOK PABDA: SILURIFORMES) IN A FISH PROCESSING PLANT
}

\author{
MD. MOTAHER HOSSAIN ${ }^{1}$, PROTIK KUMAR MOJUMDER, \\ MD. ABDUL BATEN AND MD. ABU SAYEED \\ Department of Fisheries Technology and Quality Control, \\ Sylhet Agricultural University of Bangladesh, Bangladesh
}

\begin{abstract}
The present study investigated the bacteriological quality of frozen and unfrozen pabda in a Fish Processing Plant during the period from January 2015 to October 2015. The bacteriological parameters, such as, total viable count (TVC), total coliform (TC), and the occurrence of Escherichia coli, Salmonella. spp. and Vibrio spp. were studied. The TVC of frozen samples were $2.9 \times 10^{5}, 1.8 \times 10^{5}, 1.5 \times 10^{5}, 2.5 \times 10^{5}$ and $3.5 \times 10^{5} \mathrm{CFU} / \mathrm{g}$ and the TVC of unfrozen samples were $5 \times 10^{7}, 3 \times 10^{6}, 6 \times 10^{5}, 4 \times 10^{6}$ and $4 \times 10^{7} \mathrm{CFU} / \mathrm{g}$ respectively. The mean bacterial loads of frozen and unfrozen pabda were $\log 5.37 \pm$ 0.15 and $\log 7.02 \pm 0.59$. The above results were statistically significant $(\mathrm{p}<0.05)$ between frozen and unfrozen samples of pabda.The frozen samples contained lower bacterial load than unfrozen samples. The bacterial loads of frozen pabda complied with ICMSF standard but the same of unfrozen pabda did not comply with this standard. The TC values of frozen samples were 20,15, 20, 21 and $27 \mathrm{MPN} / \mathrm{g}$ but the same values of unfrozen were $160,120,120,120$ and $150 \mathrm{MPN} / \mathrm{g}$ respectively. The mean TC values for both frozen and unfrozen samples were $20.6 \pm 4.28$ and $134 \pm 19.49$. It reveals that the TC of frozen pabda complied with ICMSF standard but the same of unfrozen pabda did not comply with this standard. The detected pathogenic bacteria were Esherichia coli, Salmonella spp. and Vibrio cholerae. In frozen Pabda all the identified pathogenic bacteria were absent. All of the unfrozen samples were contaminated with Esherichia coli, but two of the samples were contaminated with Salmonella spp. and one sample was polluted with Vibrio cholerae. So, the findings of bacteriological quality of frozen pabda complied with ICMSF standard but the same quality of unfrozen samples did not comply with ICMSF standard.
\end{abstract}

Key words: Bacteriological quality, Frozen and unfrozen pabda, Fish processing plant, ICMSF standard

\section{Introduction}

Bangladesh is blessed with rich and extensive fishery resources as well as wide variety of indigenous and exotic aquatic fauna. The soil, water and climate of Bangladesh are

1Corresponding author: E-mail: motaher03@yahoo.com 
favourable for inland fisheries production in both open and closed waters. Fish and fisheries play a dynamic role in the meeting up nutritional demand of people, generating employment and earning foreign currency (Alam 2002). There are 100 fish processing plants in Bangladesh of which 75 plants are approved by European Commission (DoF 2014).

The rivers and several haors of Sylhet district are renowned for producing fish around the year. Due to presence of haor, baor, lake and other open water bodies indigenous natural fishes are available in this region. Some cultured fishes are also available there. There are three fish processing plants in which lot of fish products are processed for export. In one plant several fish products like block frozen, IQF of fresh water fishes and other frozen white fishes are produced. Fish and fishery products are regarded as high risk commodity in respect of pathogen contents, natural toxin and other possible contaminations (Saeed et al. 2003). Microorganisms are found on outer surfaces like skin and the intestine of live newly caught fishes. Total number of bacteria found in fish skin is about $10^{2}-10^{7} \mathrm{cfu} / \mathrm{cm}^{2}$ (Liston 1980) and availability of bacterial flora in gill and intestine is $10^{3}-10^{9} \mathrm{cfu} / \mathrm{gm}$ (Shewan1977). Population densities of bacteria in water ranged from $10^{3}$ to $10^{6}$ cells in 1 $\mathrm{ml}$ of water depending on the environmental conditions. Microbial actions play an important role in the spoilage of fish (Eyo 2001). Micro flora of fish and shellfish are closely connected to these of water and sediment (Kadota 1990).

It is necessary to assess the microbial load of the processed fish products during raw and frozen state because of the presence of pathogenic bacteria like Vibrio cholerae, Salmonella spp. etc. in processed products causing serious health complexities to the consumers (Noor 2013). Ompokpabda is a tasty fish and also highly demandable for export. But no detailed research was conducted on the bacteriological quality of frozen and unfrozen pabda. Thus in the present study an attempt was taken to know the bacteriological quality of frozen and unfrozen pabda for ensuring the safety measures for the consumers.

\section{Materials and Methods}

Collection of Samples: Total five frozen samples were taken from different lots of a Fish Processing Plant and five (5) unfrozen samples taken from raw fish. All of the collected samples were transferred to Microbiological Laboratory of the plant to determine total bacterial load and total coliform and also to the Laboratory of Microbiology and Immunology Dept. of Veterinary and Animal Science Faculty of Sylhet Agricultural University, for isolating and identifying the bacteria from frozen and unfrozen samples.

Preparation of sample: Firstly $25 \mathrm{~g}$ of fish sample was taken aseptically from fish muscle, gill and intestine and was mixed homogeneously with $225 \mathrm{ml}$ distilled water in a stomacher lab blander. Each sample was mixed aseptically with sterile distilled water at the ratio of $1: 10$. Then the sample was shaken properly to make a homogenous 
suspension. Later on 10 fold serial dilutions (1:10) were prepared ranging from $10^{-2}-10^{-9}$ according to the recommendation of International Standard Organization (ISO 1995).

Calculation of total viable count (TVC): $1 \mathrm{ml}$ of each tenfold diluted sample was transferred and spreaded to plate count (PCA) agar using a sterile pipette and a sterile glass spreader. The incubated plates were then kept in an incubator at $37^{\circ} \mathrm{C}$ for $24-48$ hours. Only plates having 30 to 300 colonies were considered for counting to get their acceptable values. Number of bacteria per gram of the sample (CFU/g) was calculated by using the following formula:

$$
\begin{gathered}
\text { CFU } / \mathrm{g}= \\
\frac{\text { No. of colonies on petridish } \times 10 \times \text { dilution factor } \times \text { Volume of total sample solution }}{\text { Wt. of fish sample }(\mathrm{g})}
\end{gathered}
$$

Total coliform count (TCC): MPN (Most Probable Number) method was used to count total coliform of samples. MPN is a method to estimate the population density of viable microorganisms in a test sample. It is based upon the application of the theory of probability to the numbers of observed positive growth responses to a standard dilution series of sample inoculums placed into a set of number of culture media tubes. Positive growth response after incubation is indicated by observation of gas production in fermentation tubes. The sample was diluted in such a manner that higher dilutions of the sample would result in fewer positive culture tubes in the series. The number of sample dilutions to be prepared is generally based on the expected population contained within the sample.

Isolation and identification of pathogenic bacteria: For the isolation and identification of bacteria characters the morphological (size, shape, arrangement, and motility) were considered and study was made by Gram's staining reaction, colony characteristics, biochemical reaction, catalase test, motility test. Firstly TVC (Total Viable Count) and TCC (Total Coliform Count) were determined by using plate count agar and lactose broth. The suspected colony from these media was subcultured in Nutrient agar, VRB, EMB, MacConkey, SS, and BGA to promote the growth of a particular type of bacterium. Finally the pure culture was obtained from the selective media. Staining with "Gram's staining" method along with other tests were done. Strict aseptic measures were maintained during the period of study. Striking on different solid agar was done under laminar air flow. After performing the above mentioned tests, the results were analyzed and the isolated bacteria present in samples were identified.

Detection of Escherichia coli: For the isolation and identification of Escherichia coli, the samples were first inoculated on Violet red bile agar then the colonies from VRB agar were sub cultured on EMB, MacConkey, and BGA. Colonies on EMB agar with metallic sheen and colonies on MacConkey with pink color were suspected as positive for E. coli. The Escherichia coli were characterized by positive to indole test, catalase test, motility test and MR tests and negative to VP. 
Detection of Salmonella spp: Salmonella were grown on nutrient agar, MacConkey agar, Brilliant Green agar, Salmonella-Shigella (SS) agar and Violet Red Bile agar. On nutrient agar the Salmonella colonies were translucent, opaque, and smooth. On MacConkey agar colonies were pale or colorless. On Brilliant Green agar media was pink color and colonies were cream color. On SS agar colonies were black color with dark centre. On VRB agar colonies were pale cream color. Salmonella produced Hydrogen sulphide $\left(\mathrm{H}_{2} \mathrm{~S}\right)$ which is black color on TSI (Triple Sugar Iron) slant and SS-agar. So the slant became black in color and black colonies were grown on SS-agar. Salmonella were positive to MR test, motility test, catalase test, TSI test and negative to Indole test, VP test.

Detection of Vibrio cholerae:Vibrio cholerae was grown on nutrient agar, Thiosulfate Citrate Bile Salts Sucrose (TCBSS) agar. On nutrient agar the Vibrio spp. colonies were translucent, opaque, and smooth. On Thiosulfate Citrate Bile Salts Sucrose (TCBSS) agar Vibrio cholerae colonies appeared yellow and also green. Vibrio spp produced Hydrogen sulphide $\left(\mathrm{H}_{2} \mathrm{~S}\right)$ which is yellow in color on TSI (Triple Sugar Iron) slant. Vibrio cholerae was positive to MR test, motility test, catalase test, and TSI test and negative to VP test.

Statistical analysis: For preliminary processing of raw data obtained from both unfrozen and frozen pabda, the mean, standard deviation was calculated first. These values were useful and other statistical analysis and interpretations thereafter were done by using the computer software like Microsoft Excel.

\section{Results and Discussion}

The results of bacteriological quality of frozen and unfrozen Pabda (Ompokpabda) from the fish processing plant are presented in Tables 1 and 2 . In this study selected bacteriological qualities were TVC, TC, E.coli, Salmonella and Vibrio cholerae. From both type of samples all the findings were verified with ICMSF standard 1986 for the acceptable or unacceptable in terms of export and as well as food safety for the consumer.

Table 1. Total results for unfrozen pabda collected from Processing Plant before processing.

\begin{tabular}{ccccccccc}
\hline $\begin{array}{c}\text { Raw samples of } \\
\text { specific lot }\end{array}$ & Date & $\begin{array}{c}\text { TVC } \\
\text { (CFU/g) }\end{array}$ & $\begin{array}{c}\text { log TVC } \\
\text { (CFU/g) }\end{array}$ & TC & $\begin{array}{c}\text { E. Salmonella } \\
\text { coli }\end{array}$ & $\begin{array}{c}\text { Vibrio } \\
\text { cholerae }\end{array}$ & Remarks \\
\hline 1 & $05 / 01 / 15$ & $5 \times 10^{7}$ & 7.698 & 160 & $\mathrm{P}$ & $\mathrm{P}$ & $\mathrm{P}$ & Results did \\
2 & $01 / 03 / 15$ & $3 \times 10^{6}$ & 6.477 & 120 & $\mathrm{P}$ & $\mathrm{A}$ & $\mathrm{A}$ & not \\
comply \\
3 & $20 / 04 / 15$ & $6 \times 10^{5}$ & 6.698 & 120 & $\mathrm{P}$ & $\mathrm{P}$ & $\mathrm{A}$ & with \\
4 & $14 / 05 / 15$ & $4 \times 10^{6}$ & 6.602 & 120 & $\mathrm{P}$ & $\mathrm{A}$ & $\mathrm{A}$ & ICMSF \\
5 & $29 / 07 / 15$ & $4 \times 10^{7}$ & 7.602 & 150 & $\mathrm{P}$ & $\mathrm{A}$ & $\mathrm{P}$ & standard \\
\hline
\end{tabular}


Table 2. Total results for frozen pabda collected from Processing Plant after processing.

\begin{tabular}{clllllllc}
\hline $\begin{array}{l}\text { Lot } \\
\text { no. }\end{array}$ & Date & $\begin{array}{l}\text { TVC } \\
\text { (CFU/g) }\end{array}$ & $\begin{array}{l}\text { log TVC } \\
(\mathrm{CFU} / \mathrm{g})\end{array}$ & TC & $\begin{array}{c}\text { Esherichia } \\
\text { coli }\end{array}$ & $\begin{array}{c}\text { Salmo } \\
\text { nella }\end{array}$ & $\begin{array}{c}\text { Vibrio } \\
\text { cholerae }\end{array}$ & Remarks \\
\hline 1 & $26 / 02 / 15$ & $2.9 \times 10^{5}$ & 5.462 & 20 & $\mathrm{~A}$ & $\mathrm{~A}$ & $\mathrm{~A}$ & Results \\
2 & $02 / 04 / 15$ & $1.8 \times 10^{5}$ & 5.255 & 15 & $\mathrm{~A}$ & $\mathrm{~A}$ & $\mathrm{~A}$ & complied \\
3 & $04 / 05 / 15$ & $1.5 \times 10^{5}$ & 5.176 & 20 & $\mathrm{~A}$ & $\mathrm{~A}$ & $\mathrm{~A}$ & with \\
4 & $07 / 06 / 15$ & $2.5 \times 10^{5}$ & 5.397 & 21 & $\mathrm{~A}$ & $\mathrm{~A}$ & $\mathrm{~A}$ & ICMSF \\
5 & $20 / 08 / 15$ & $3.5 \times 10^{5}$ & 5.544 & 27 & $\mathrm{~A}$ & $\mathrm{~A}$ & $\mathrm{~A}$ & standard \\
\hline
\end{tabular}

Total Viable Count of bacteria: The concentration of TVC was calculated both for frozen and unfrozen pabda. The collected samples of the frozen pabda contained lower bacterial load than unfrozen pabda of this plant. The TVC of frozen samples was $2.9 \times 10^{5}, 1.8 \times 10^{5}$, $1.5 \times 10^{5}, 2.5 \times 10^{5}$ and $3.5 \times 10^{5} \mathrm{CFU} / \mathrm{g}$; on the other hand, TVC of unfrozen samples was $5 \times 10^{7}, 3 \times 10^{6}, 6 \times 10^{5}, 4 \times 10^{6}$ and $4 \times 10^{7} \mathrm{CFU} / \mathrm{g}$ respectively The bacterial load of frozen pabda complied with ICMSF standard but failed in case of unfrozen pabda.

Comparative Analysis of Bacterial Load (TVC) : The mean of bacterial load was calculated as Log CFU \pm SD. The mean bacterial load determined for both frozen and unfrozen samples were $\log 5.3668 \pm 0.150232$ and $\log 7.0154 \pm 0.585568$ (Fig. 1). The above results were statistically significant $(\mathrm{p}<0.05)$ between frozen and unfrozen samples of pabda.

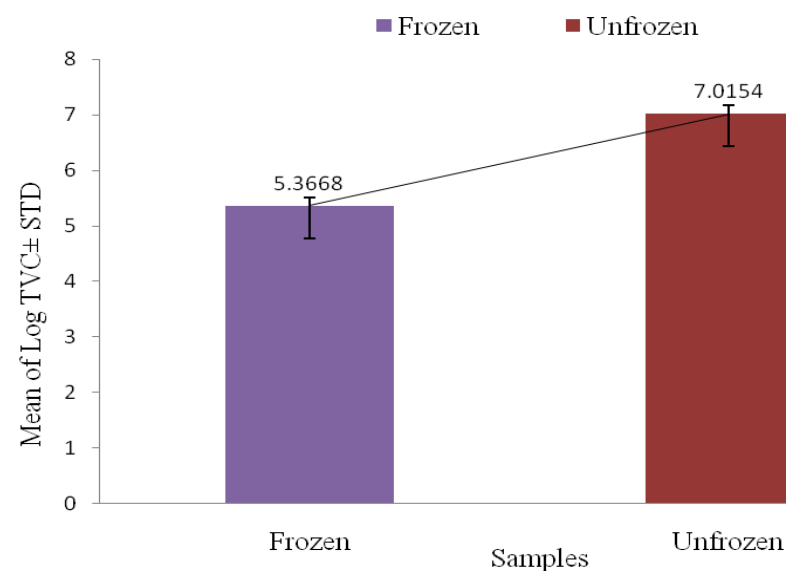

Fig. 1.Comparison of total bacterial load (TVC) of frozen and unfrozen pabda.

Total Coliform (TCC) Count: Total Coliform (TC) was calculated by using Most Probable Number (MPN) index. The frozen Pabda contained lower total coliform than unfrozen pabda of the collected samples of this plant. The TC of frozen samples was 20 , 15, 20, 21 and 27 MPN/g whereas the same of unfrozen samples was 160, 120, 120, 120 
and $150 \mathrm{MPN} / \mathrm{g}$. The total coliform of frozen pabda complied with ICMSF standard but in case of unfrozen pabda did not comply with this standard.

Comparative Analysis of Total Coliform (TC): The mean of total coliform was calculated as $\log$ MPN $/ g \pm$ SD. The mean total Coliform determined for both frozen and unfrozen samples were $20.6 \pm 4.27785$ and $134 \pm 19.49359$ (Fig. 2).

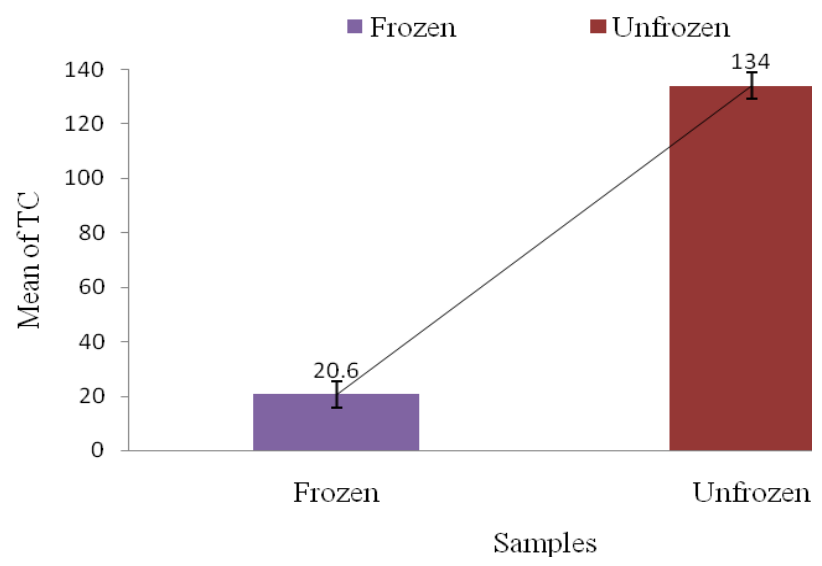

Fig. 2. Comparison of Total Coliform (TC) of frozen and unfrozen pabda.

Pathogenic bacteria in frozen and unfrozen pabda: In frozen pabda pathogenic bacteria was absent. All of the frozen samples were safe due to the absence of pathogenic bacteria but in unfrozen samples pathogenic bacteria were present. The identified bacteria were Esherichia coli, Salmonella spp. and Vibrio cholerae.

During this experiment frozen and unfrozen pabda were taken from a plant and studied to find the bacterial load of the sesamples. The TVC of frozen samples were $2.9 \times 10^{5}$, $1.8 \times 10^{5}, 1.5 \times 10^{5}, 2.5 \times 10^{5}$ and $3.5 \times 10^{5} \mathrm{CFU} / \mathrm{g}$, whereas TVC of unfrozen samples were $5 \times 10^{7}, 3 \times 10^{6}, 6 \times 10^{5}, 4 \times 10^{6}$ and $4 \times 10^{7} \mathrm{CFU} / \mathrm{g}$ respectively. The mean bacterial load of frozen and unfrozen pabda was $\log 5.3668 \pm 0.150232$ andlog7.0154 \pm 0.585568 . The frozen samples contained lower bacterial load than unfrozen samples. The bacterial load of frozen pabda complied with ICMSF standard but unfrozen pabda did not comply with this standard. The findings of this experiment were almost similar to the previous report Saeed et.al (2003) who found that the bacterial load of frozen Hilsha (Tenualosa ilisha) in four lots were $1.33 \times 10^{5}, 1.05 \times 10^{5}, 0.63 \times 10^{5}$ and $0.49 \times 10^{5} \mathrm{cfu} / \mathrm{gm}$ and also in the same species of unfrozen Hilsha were $9.75 \times 10^{5}, 7.50 \times 10^{5}, 4.40 \times 10^{5}$ and $3.71 \times 10^{5} \mathrm{cfu} / \mathrm{gm}$. SPC of frozen Hilsha was lower than that of the unfrozen Hilsha fish collected from different markets and habitats. Khan (2012) compared the microbial analysis between frozen and raw shrimp in "ARK Sea Foods Ltd." in Chittagong, Bangladesh. During this study the mean TVC \pm SEM of raw and frozen shrimp were $4.37 \pm 0.328 \times 10^{5}$ and $1.42 \times 10^{5} \pm$ $0.187 \times 10^{5}$ respectively. The TC of frozen samples of the present study was $20,15,20$, 
21 and $27 \mathrm{MPN} / \mathrm{g}$, where the TC of unfrozen samples was 160, 120, 120, 120 and 150 MPN/g. The mean Total Coliform determined for both frozen and unfrozen samples were $20.6 \pm 4.27785$ and $134 \pm 19.49359$. The Total Coliform of frozen Pabda complied with ICMSF standard but unfrozen pabda did not comply with this standard. According to ICMSF (1986) the acceptable limit of total coliform is $<100 \mathrm{MPN} / \mathrm{g}$. The present result wasfound with the findings of Saeed et al. (2003) in frozen and unfrozen Hilsha. Ali et al. (2012) observed that the mean total coliform count of cooked IQF shrimp was $<3 \pm$ $0.00 \mathrm{MPN} / \mathrm{g}$, while it was $23.50 \pm 13.72 \mathrm{MPN} / \mathrm{g}$ in Raw Block Frozen Shrimp which support the present study. The pathogenic bacteria isolated and identified during this experiment were Esherichia coli, Salmonella spp. and Vibrio cholerae. In frozen pabda all of the identified pathogenic bacteria were absent. So, it may be mentioned that frozen samples complied with ICMSF standard. In case of all frozen Hilsha, Salmonella spp. and Vibrio cholerae were absent (Saeed et al. 2003). The study was conducted to determine the microbial quality of Tenualosa ilisha at different stages of processing. There was no evidence of presence of Salmonella and Vibrio cholerae at any stages of processing (Shamsuzzaman et al. 2011).

In unfrozen samples pathogenic bacteria were present. All the unfrozen samples were contaminated with Esherichia coli, two of the samples contaminated with Salmonella spp. and one sample polluted with Vibrio cholerae. The unfrozen samples did not comply with ICMSF standard. According to ICMSF (1986), zero tolerance of Salmonella spp. and Vibrio cholerae is in fish and fishery products. Salmonella spp. in aquaculture shrimp products mainly originates from the environment rather than from poor standards of hygiene and sanitation. But sometimes, incidence of this bacterium in fish, shrimp or similar foods of aquatic habitats may happened due to external contamination (Huss 1993). Salmonella was isolated from fresh, frozen, canned and sun dried marine fish products (Natarajan et al. 1985).

The findings of the bacteriological quality of frozen pabda were quite satisfactory and also complied with ICMSF standard. It was due to the proper processing of raw fish. After complied with this standard it is considered for export having health certificate from FIQC, DoF for export to EU and other countries. On the other hand, bacteriological quality of unfrozen pabda was not satisfactory and it did not comply with ICMSF standard due to the presence of higher bacterial load and pathogenic bacteria. So, the study reveals that frozen pabda was better than unfrozen pabda considering food safety as well as for export.

\section{References}

Alam, M. F. 2002. Socioeconomic aspects of carp production and consumption in Bangladesh. In: Penman, Proceedings of a workshop on Genetic Management and Improvement Strategies for Exotic Carps in Asia. Dhaka, Bangladesh. Bangladesh Fisheries Research Institute, Mymensingh, Bangladesh.pp 83-93. 
Ali, M.Y., M. Belal Hossain and M. Shamsuddin. 2012. "Microbiological Status in a Fully Exportoriented Shrimp Processing Plant", World Applied Sciences Journal, 16: 903-906.

Deapartment of Fisheries (DoF). 2014. Matsha pakkha sankalon, Department of fisheries, Dhaka, Bangladesh.

Eyo, A.A. 2001. Fish processing Technology in the Tropics. Published by National Institute for Freshwater Fisheries Research (NIFFR), P.M.B. 6006, and New Bussa, Niger State, pp. 37-39, 130-138-153-160-164

Huss, H.H. 1993. Assurance of Seafood quality. FAO Fisheries Technical Paper, Rome, pp. 94, 97, 169.

ICMSF (International Commission on Microbiological Specification for Foods). 1986 Microorganisms in Foods (Vol. 2). Sampling for microbiological analysis: Principles and specific applications. $2^{\text {nd }}$ ed. Blackwell Scientific Publications.

ISO (International Standard Organisation). 1995. Recommendation of the meeting of the subcommittee, International Organization forStandardization, on meat and meat products. ISO/TC-36/Sc-6. The Netherlands.10-18.

Kadota, H. 1990. Spoilage of marine products. In: science of processing marine food products. Vol.1. Japan Internationals Cooperation Agency, Hyogo Internationals Centre, pp. 60-76.

Khan, N.S., M.R. Islam, M.B.Hossain, M.A.Quaiyum, M.Shamsuddin and K. K. Jibon. 2012 Comparative Analysis of Microbial Status of Raw and Frozen Freshwater Prawn (Macrobrachium rosenbergii), Middle-East Journal of Scientific Research. 12(7): 10261030.

Liston, J. 1980. Microbiology in fishery science. In: Connell, J.J. (ed.) Advances in fishery science and technology, Fishing News Books Ltd., Farnham, England, 138-157.

Natarajan, R., M.T. Rama and S. Ramesh. 1985. Salmonella in marine food products- a review. In: Harvest and Post-harvest Technology of Fish. Society of Fisheries Technologists (India), pp: 658.

Noor, R. 2013. Microbiological study of major sea fish available in local markets of Dhaka city, Bangladesh. J. Microb. Biotech. Food Sci. 2(4): 2420-2430.

Saeed, S., M.M. Hossain, G. B. Sufi and M.U. Ahmed. 2003. Bacteriological quality of Tenualosailisha (Hamilton) in a Freezing plant. Dhaka University Journal of Biological Science 12(2): 223-227.

Shamsuzzaman, M. M., S. K. Mazumder, M.A. Siddique and M. N. U. Miah. 2011. Microbial quality of hilsa shad (Tenualosailisha) at different stages of Processing. Journal of Bangladesh Agricultural University. 9(2): 339-344.

Shewan, J.M. 1977. The bacteriology of fresh and spoiling fish and the biochemical changes induced by bacterial action. In: Proceedings of the Conference on Handling, Processing and Marketing of Tropical Fish. Tropical Products Institute, London, 51-66. 